\title{
Microcircuitry of Beta Ganglion Cells in Cat Retina
}

\author{
Barbara A. McGuire, John K. Stevens, ${ }^{1}$ and Peter Sterling \\ Department of Anatomy, School of Medicine, University of Pennsylvania, Philadelphia, Pennsylvania 19104
}

\begin{abstract}
We reconstructed from electron micrographs of 189 serial ultrathin sections a major portion of the dendritic tree of an on- $\beta$ ganglion cell through its sixth order of branching. One hundred three contacts from three cone bipolar cells were identified. Forty-seven contacts were from a single $\mathrm{CBb}$, cone bipolar. These were distributed widely over the dendritic tree but were frequently found on the slender "basal tuft" dendrites. Twenty-two additional contacts from a second $\mathrm{CBb}_{1}$ cell were found but not studied in detail. Thirty-four contacts were from a single $\mathbf{C B h}_{2}$ cone bipolar; these also were distributed widely but were primarily on the branches of the main dendritic arborization. A major portion of the dendritic tree of an off- $\beta$ cell was also reconstructed through its seventh order of branching. Thirtyfive contacts from two cone bipolar cells were identified. Twenty-three contacts were from a single $\mathrm{CBa}_{1}$ cone bipolar and 12 were from a single $\mathrm{CBa}_{2}$ cone bipolar; both sets of contacts were widely distributed over the off- $\beta$ cell dendritic tree.

We propose that the photopic receptive field center of a $\beta$ cell corresponds to the envelope of the receptive fields of the bipolar cells that connect it to the cones. The center response of a $\beta$ cell may be generated by a "push-pull" mechanism. For the on- $\beta$ cell there would be excitation at light on from $\mathrm{CBb}_{1}$ and disinhibition from $\mathrm{CBb}_{2}$ and the reverse at light off. For the off- $\beta$ cell there would be inhibition at light on from $\mathrm{CBa}_{2}$ and withdrawal of excitation from $\mathrm{CBa}_{1}$. Should the bipolars have antagonistic surrounds (so far reported only for $\mathbf{C B b} b_{1}$ ), the $\beta$ cell surrounds as well as their centers might be generated by this push-pull mechanism.
\end{abstract}

The "X"-cell is among the best defined of the various physiological categories of retinal ganglion cell. It has a small receptive field with the classic, center-surround antagonism, linear spatial summation, and medium axonal conduction velocity. The response to a light stimulus is brisk and sustained (Cleland and Levick, 1974; Cleland et al., 1971; Enroth-Cugell and Robson, 1966; Fukuda, 1971; Kuffler, 1953). Boycott and Wässle (1974) identified an anatomical class of ganglion cell, which they called "beta," with a small dendritic tree and a medium-sized soma and axon, and suggested that it corresponded to the X-cell. Beta cells with dendrites branching in sublamina $b$ of the inner plexiform layer were thought to be on-center, and those with den-

\footnotetext{
Received Feb. 14, 1985; revised July 3, 1985; accepted July 3, 1985.

This work was supported by NIH Grants EY01832, EY00828, and EY01583 and a Research Career Development Award (EY00080) to P.S. During part of this work, J.K.S. was supported by a Canadian MRC grant. We thank Neil Friedman and Robert $G$. Smith for their computer assistance, Fred Letterio, Ed Shalna and Alfred M. Reingold for technical support, Donna Heaney, John R. Megill, and Debby Netsky for technical help, and Susan Heumiller for help with the illustrations. We also thank Robert Smith and Drs. Michael Freed, James Hamos, and Jürgen Bolz for useful discussions.

Correspondence should be sent to Barbara McGuire's current address: The Rockefeller University, Box 138, 1230 York Avenue, New York, NY 10021.

' Present address: Department of Physiology, Playfair Memorial Neuroscience Unit, Toronto Western Hospital, 399 Bathurst Street, Toronto, Ontario M5T 2S8, Canada.

Copyright (-) 1986 Society for Neuroscience $0270-6474 / 86 / 040907-12 \$ 02.00 / 0$
}

drites branching in sublamina a to be off-center (Nelson et al., 1978; Wässle et al., 1981a). Direct proof of this hypothesis by intracellular recording and dye injection has recently been published by several investigators (Fukuda et al., 1984; Saito, 1983; Stanford and Sherman, 1984). Once the link was established between the physiology and morphology of these two types of ganglion cell, it was possible to study their microcircuitry with the hope of understanding the basis for the receptive field structure (Kolb, 1979; Stevens et al., 1980b).

Most of the inputs to a $\beta$ ganglion cell are from cone bipolar cells (Kolb, 1979). In a previous paper (McGuire et al., 1984), we showed that the on- $\beta$ cell receives convergent inputs from at least two types of cone bipolar cells arborizing in sublamina $b$, and that, likewise, the off- $\beta$ cell receives convergent inputs from at least two types of cone bipolar cells arborizing in sublamina a. Here we have reconstructed for an on- $\beta$ cell and an adjacent off- $\beta$ cell the detailed patterns of synaptic contact made on each ganglion cell by two different types of cone bipolar cell. This microcircuitry, along with information about the bipolar cells' physiology (Nelson and Kolb, 1983), suggests a possible mechanism for the generation of the $\beta$ cell's photopic receptive field. Summaries of this study have appeared previously (McGuire et al., 1980, 1982; Sterling, 1983).

\section{Materials and Methods}

Two ganglion cells were reconstructed from electron micrographs of 189 serial sections using the same tissue and methods as in a previous paper (McGuire et al. 1984; see also Stevens et al., 1980a). The positions of synaptic contacts from four different types of cone bipolar cell previously reconstructed (cells 1, 4, 5, and 6; McGuire et al., 1984) were mapped on the digitized outlines of the ganglion cell profiles.

The precise dendritic placement of each synaptic contact was often difficult to determine directly from the computer reconstruction in which the cell's bushy, three-dimensional dendritic tree was collapsed into a two-dimensional representation. It was therefore necessary to construct a branch diagram (e.g., Fig. 5) that conveyed more clearly the dendritic lengths, the positions of branch points, and the locations of synaptic contacts. This was accomplished by identifying, section by section, every branch point on the $\beta$ cell. The length of a dendrite cut longitudinally was measured directly from electron micrographs. The length of each dendrite sectioned obliquely or transversely was estimated by adjusting the measured length proportionally for the number of sections in which it appeared. On the diagram constructed from these measurements, the synaptic contacts from the pair of bipolar cells were placed in their appropriate positions. The branch diagram accurately shows the relative lengths of the dendrites, the relative positions of the two sets of inputs, and the number of branch points and dendrites included in the reconstruction. The branch diagrams in this report do not include information about the following: dendritic diameters; absolute laminar locations of the dendrites; which of the dendritic branches extended beyond the series; or the positions of additional amacrine or bipolar cell synaptic inputs.

\section{Results}

Two adjacent $\beta$ ganglion cells were reconstructed from a region within $2^{\circ}$ of the center of the area centralis (Fig. 1). The soma diameter of the first cell, the on- $\beta$ cell (Fig. 1, left) was $15.3 \mu \mathrm{m}$ 


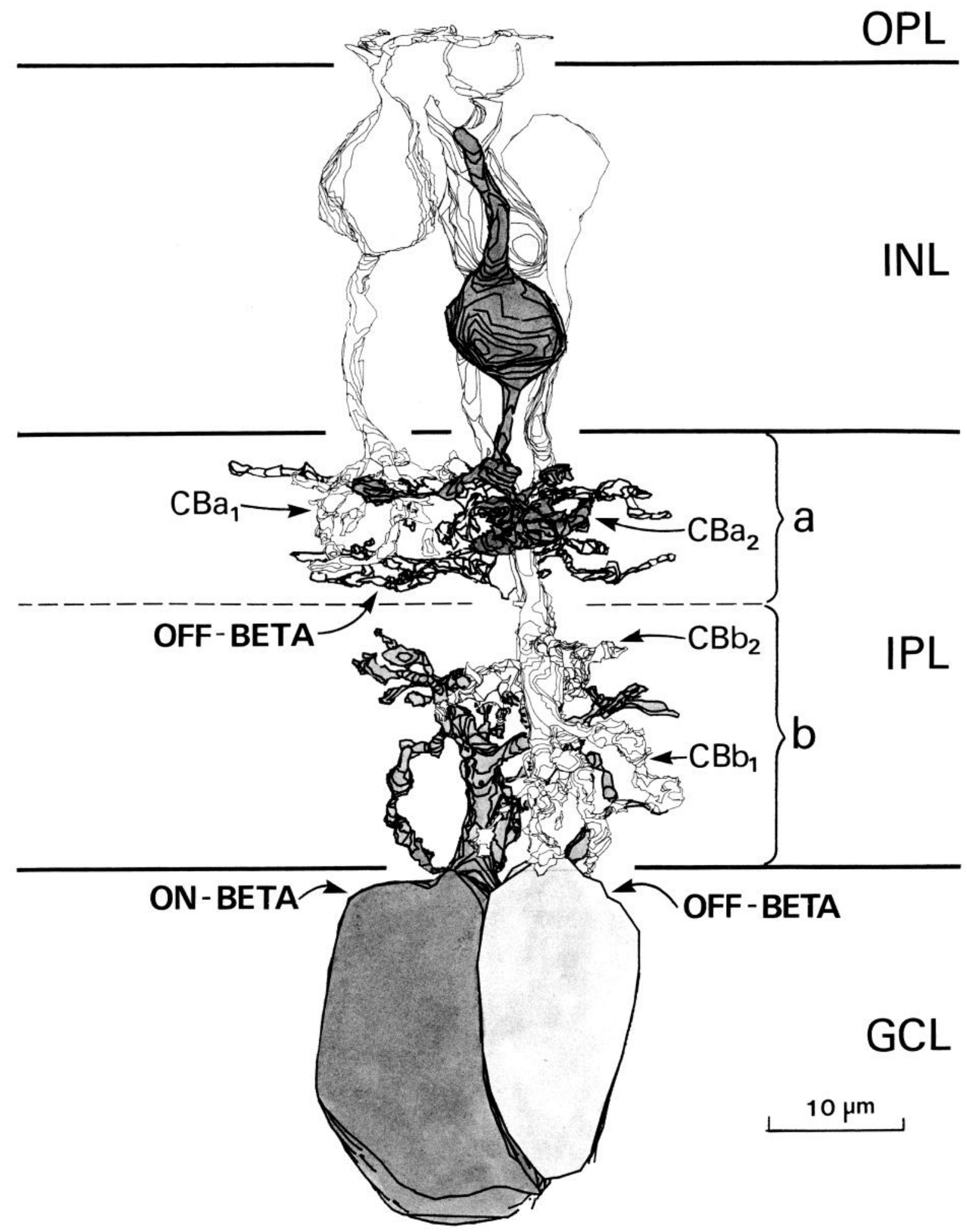

Figure 1. Computer reconstructions of both $\beta$ ganglion cells with their pairs of presynaptic bipolar cells placed in their approximate positions in the tissue. The somas of the $\beta$ cells are adjacent in the ganglion cell layer, and their dendritic arbors (thicker outlines) are co-spatial in the tangential plane. The bipolar cells' cell numbers are from McGuire et al. (1984): $\mathrm{CBa}_{1}$ (Cell 1), unshaded, upper left soma; $\mathrm{CBa}_{2}$ (5), dark shading; $\mathrm{CBb}_{1}(6)$, unshaded, upper right soma; and $\mathrm{CBb}_{2}(4)$, medium shading, middle soma. $O P L$, outer plexiform layer; $I N L$, inner nuclear layer; IPL, inner plexiform layer; $G C L$, ganglion cell layer.

measured parallel to the vitreal surface. The cell body was elongated perpendicular to the vitreal surface, as previously described for $\beta$ cells (Kolb, 1979; Stevens et al., 1980b). The dendritic tree arborized directly above the soma within all three strata (S3-5) of sublamina b of the inner plexiform layer (Figs. 1 and 2; see Nelson et al., 1978; Wässle et al., 1981a). The dendritic cytoplasm was pale in the proximal dendrites but gradually darkened toward the distal portions-as in previous de- 


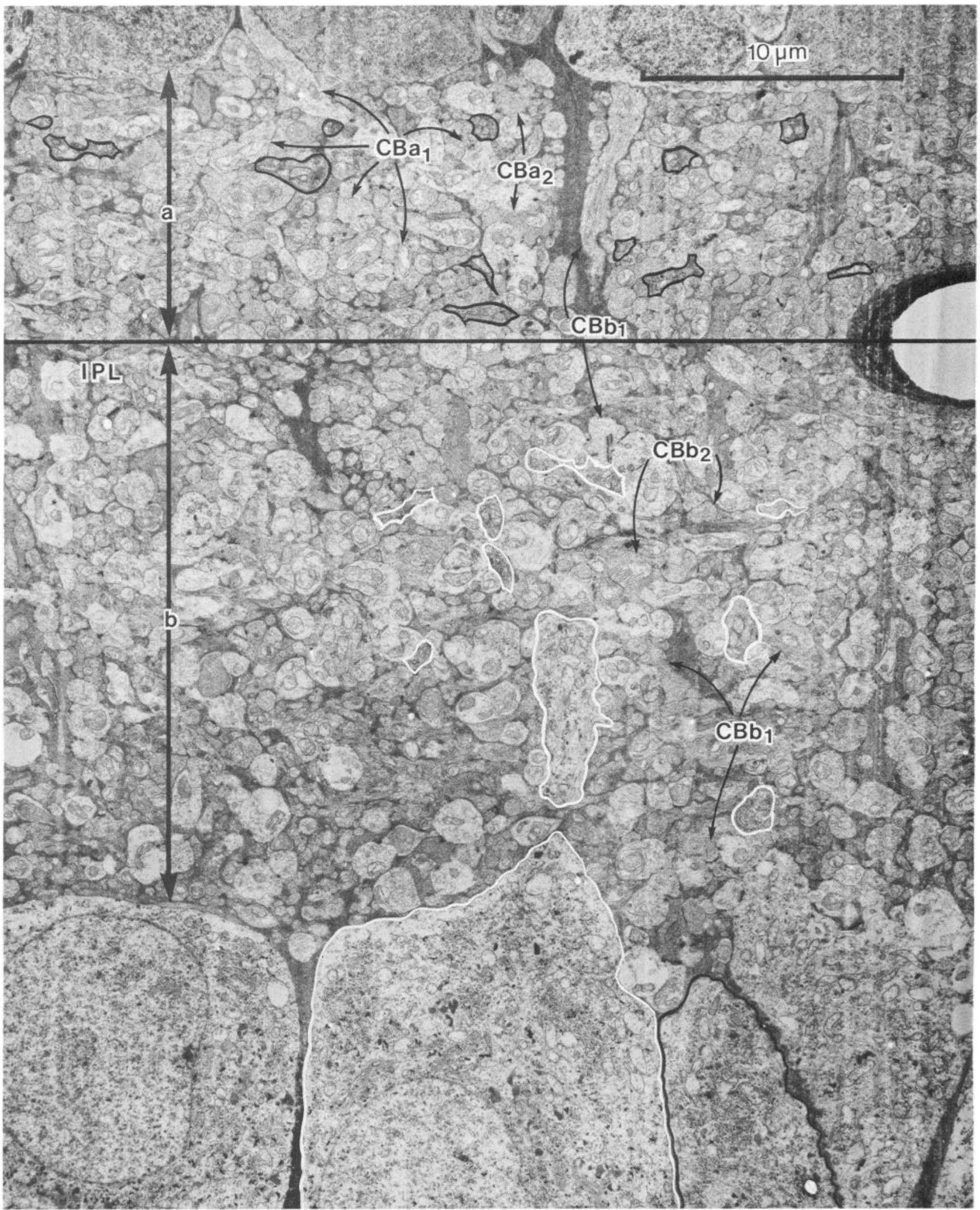

Figure 2. Electron micrograph of section 49, from the original series of electron micrographs. Profiles of the four different presynaptic cone bipolar cells are indicated. The on- $\beta$ cell is outlined in white, and the off- $\beta$ in black. Many disconnected profiles of a single cell (e.g., the on- $\beta$ ) can be present in a single section. Even after six neighboring cells have been reconstructed, most of the profiles in the surrounding neuropil remain unidentified. 
Figure 3. Schematic line drawing of five $\beta$ cells that received multiple inputs from cone bipolars. Soma profiles were traced from the largest cross section within the series. Nuclei and nucleoli are drawn in if present within the series. $A$ and $B$, The two $\beta$ cells described in detail here; $C$, presumed on $\beta$, due to its basal tuft and inputs from $\mathrm{CBb}_{1} ; D$, an on $\beta$ receiving convergent input from two $\mathrm{CBb}_{1}$ cells; $\mathrm{E}$, an off- $\beta$, whose dendritic tree is connected to its soma within series, receiving convergent $\mathrm{CBa}$ and $\mathrm{CBa}_{2}$ inputs.

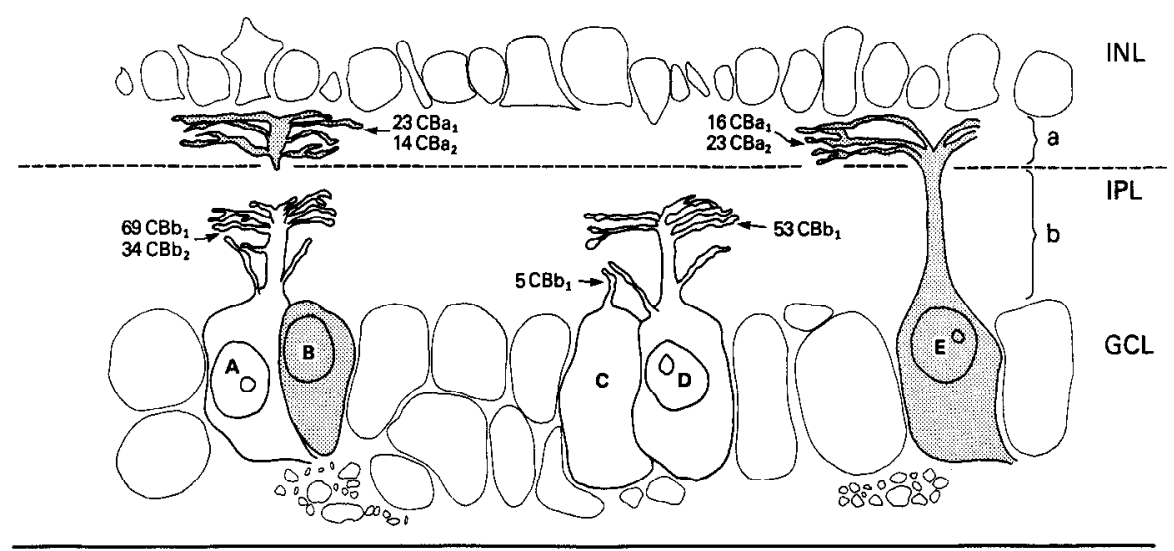

$10 \mu \mathrm{m}$ scriptions of $\beta$ cells (Stevens et al., 1980b) - such that by the time the dendrites had reached the third order of branching, their cytoplasm was dark (Fig. 2). The medium-sized cell body, bushy and narrow-field dendritic tree, and sublamina $b$ dendritic arborization are the classic features of $\beta$ ganglion cells of the on-center variety (Boycott and Wässle, 1974; Kolb et al., 1981).

The identity of the second reconstructed neuron (Fig. 1, lower right) was at first less secure, because most of the primary dendrite was cut away before the series began, but for several reasons outlined here we believe it must be an off- $\beta$ cell. First, the reconstructed dendritic tree arborized within both strata of sublamina $b$ of the inner plexiform layer (see Figs. 1 and 2), forming a narrow-field, bushy arbor. As with the on-cell, the dendritic cytoplasm was dark (Fig. 2). The region of the primary dendrite connecting the soma and main arborization of the off- $\beta$ cell was cut away, but it is certain that the two were connected because the off- $\beta$ cell had the only soma in an appropriate position in the ganglion cell layer to join with the primary dendrite. This cell body, sitting immediately adjacent to that of the on- $\beta$ cell, had an apparent diameter of $11 \mu \mathrm{m}$ (Fig. 1) but was actually larger, since it had not reached its maximum diameter within the series. This is consistent with the fact that the nucleolus of this cell was not present within the series (Fig. 3, cell B). The reconstructed dendrites of this second cell corresponded in lamination, cytological appearance, bushy and narrow-field branching pattern, as well as presynaptic bipolar cell types to a second cell we traced but did not reconstruct three-dimensionally within the series (Fig. 3, cell E). Cell E, whose dendritic arbor was connected to its soma by a single primary dendrite that did not branch within sublamina $b$, had a cell body diameter of $16 \mu \mathrm{m}$. Thus, it displayed all the characteristics of an off- $\beta$ ganglion cell. The close correspondence of these two neurons convinced us that the incompletely reconstructed dendritic tree was also an off- $\beta$ cell.

It is quite unlikely that the off- $\beta$ cells could correspond to any of the other narrow-field ganglion cells described by Kolb et al. (1981). For example, cell types G6, G7, and G8 each branch in a single stratum within sublamina a, while our off- $\beta$ cells each branched throughout the sublamina. Nor could they correspond to cell type G9, because off- $\beta$ cell $E$ did not branch at all in sublamina $b$, whereas $G 9$ of Kolb et al. branches diffusely within both sublaminae. A correspondence with cell type G5 of Kolb et al. could also be ruled out because its cell body size $(9 \mu \mathrm{m})$ is smaller than that of either off- $\beta$ cell shown here.

\section{On-beta cell}

The main arborization of the on- $\beta$ cell consisted of a single, stout primary dendrite (1.9 $\mu \mathrm{m}$ diameter) that ascended un- branched through stratum 5 (Fig. 4) and emitted six secondary branches in strata 4 and 3 (Figs. 4 and 5). Five of these secondary branches bifurcated and gave rise in strata 4 and 3 to 29 branches of the third through sixth order. The combined lengths of all 52 reconstructed dendrites was $196 \mu \mathrm{m}$, most of which $(80 \%)$ was accounted for by dendrites of the second through fourth order. We distinguished from the main arborization a second group of dendrites arising either from the base of the stout primary dendrite or directly from the soma (Figs. 4 and 5). These we called basal tufts. Three basal tuft dendrites were identified, and a bulge on the front of the soma suggested there might be a fourth, symmetrically placed basal tuft that had been cut away (Fig. 1). Two of the basal tufts branched, one reaching the sixth order like the main arborization, but they remained within strata 5 and 4 , closer to the ganglion cell layer than the main arborization. These basal tuft dendrites have been an unappreciated fealure of the dendritic tree of on- $\beta$ cells, although they were present in earlier reconstructions (Stevens et al., 1980b).

A tangential view of the reconstructed dendritic tree (obtained by rotating the reconstruction $90^{\circ}$ about the $x$-axis) is shown at the top of Figure 4 and again in Figure 6. The smallest circle that would include the most distal reconstructed dendritic tips is $25 \mu \mathrm{m}$, and within such a circle the reconstruction would appear more than half complete. The dendritic tree diameters of $\beta$ cells labeled by the Golgi technique (earlier figures corrected for linear shrinkage by a factor of 0.77 ; see Peichl and Wässle, 1979) range from about $20-30 \mu \mathrm{m}$ in the area centralis to between 50 and $120 \mu \mathrm{m}$ at $5^{\circ}$ out (Boycott and Wässle, 1974; Kolb et al., 1981; Peichl and Wässle, 1979). Given this range, a reasonable estimate of the diameter of an on- $\beta$ cell at $2^{\circ}$ eccentricity is somewhere between 25 and $45 \mu \mathrm{m}$. It is impossible, of course, to determine the dendritic diamcter of this on- $\beta$ ccll absolutely, and although we believe our reconstruction is inclusive of most of the dendrites within the series, it is still conceivable that some of the finest branches could have been lost. Nevertheless, we suggest that the diameter of the on- $\beta$ cell reconstructed here is between 30 and $35 \mu \mathrm{m}$ and have represented this figure as a 35 $\mu \mathrm{m}$ diameter circle inscribed on the rotated reconstruction in Figure 6.

\section{Off-beta cell}

The primary dendrite of the off- $\beta$ cell emitted four secondary branches in strata 2 and 1 . Each secondary branch then branched further, giving rise to a total of 36 branches of the third through seventh order (Figs. 7 and 8). These dendrites tended to cluster horizontally in the middle of stratum 1 and the middle of stratum 2 (Fig. 7). Additional examples will be needed to determine whether this bistratification within sublamina a is typical. The 

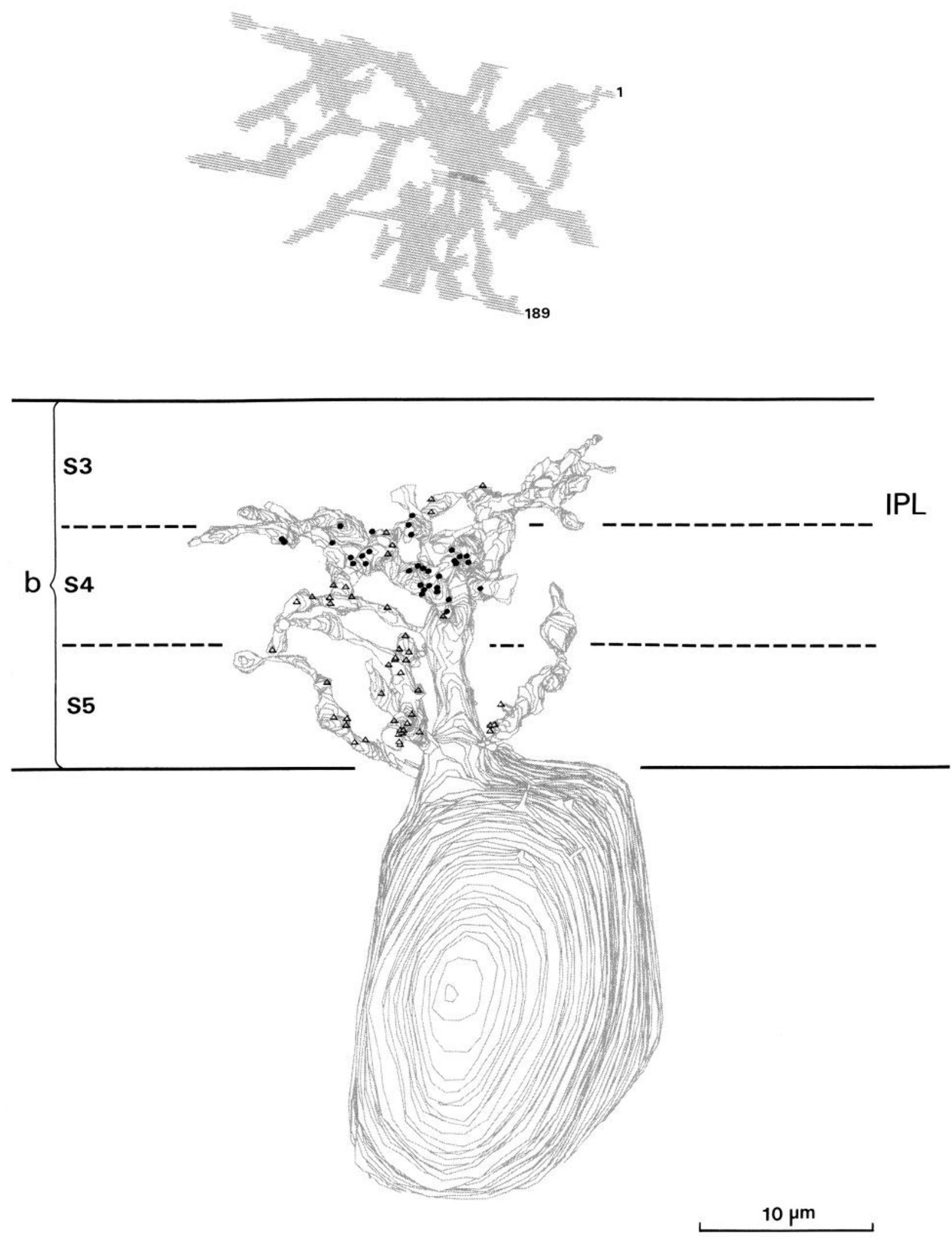

Figure 4. Below, Computer reconstruction of on- $\beta$ cell, as seen from the rear of the series. Three "basal tuft" dendrites branch from the top of the soma, two from the base of the stout primary dendrite in front, and one directly from the soma in rear; all arborize in S4-5, and receive only $\mathrm{CBb}_{1}$ contacts $(\triangle)$. Dendrites of the main arborization branch from the primary dendrite and arborize in $\mathrm{S} 3-4$, receiving all of the $\mathrm{CBb}_{2}$ contacts (๑) and the remainder of the $\mathrm{CBb}_{1}$ contacts. (Reproduced, with permission, from the Annual Review of Neuroscience 6. Copyright 1983 by Annual Reviews Inc.) Above, Projection of the reconstructed dendritic arbor of the on- $\beta$ cell as if seen in a flat-mount, with first and last sections indicated. 


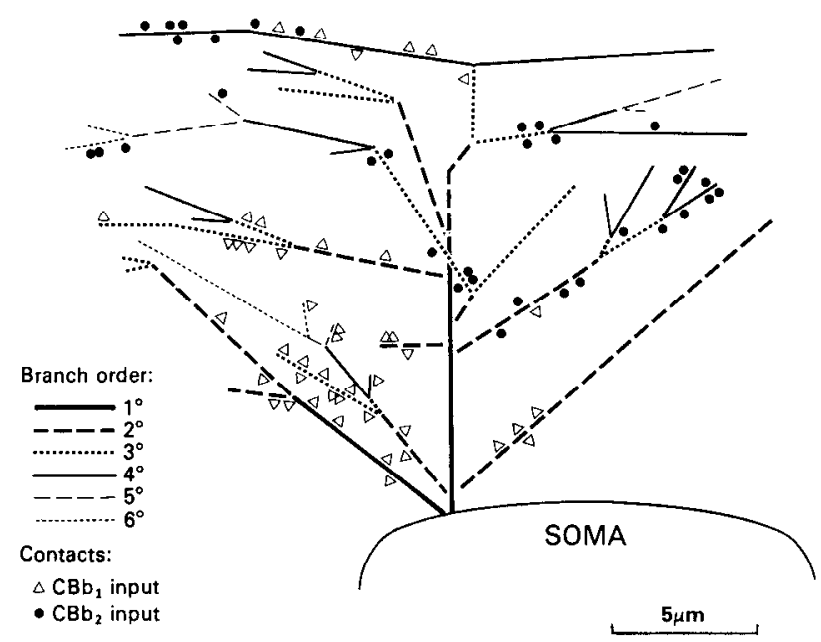

Figure 5. Branch diagram, on- $\beta$ cell. Each dendritic branch was measured in length, taking into account the depth of the series and the number of sections within which it was present. (These lengths are represented here in a single plane, so that dendritic lengths can be measured from the diagram.) Synaptic contacts from $C B b_{1}(\triangle)$ and $C B b_{2}$ (O) inputs were then placed in their approximate positions along dendrites. The stout primary dendrite emitted six slender dendrites before narrowing and bifurcating, so we arbitrarily called it a primary dendrite throughout its stout length. Every other dendrite increased one branch order after bifurcating. (Reproduced, with permission, from the Annual Review of Neuroscience 6. Copyright 1983 by Annual Reviews Inc.)

combined length of all 41 reconstructed branches was $169 \mu \mathrm{m}$, most of which (80\%) was accounted for by dendrites of the third through fifth order. Thus, the total dendritic length reconstructed is of the same order as for the on- $\beta$ cell.

The dendritic tree is shown in tangential view in Figure 7. The diameter of the smallest circle that includes the most distal reconstructed dendritic tips would be $32 \mu \mathrm{m}$, and within this circle, the reconstruction is almost half complete. As with the on- $\beta$ cell, however, since the cell was not filled by any intracellular label, we do not know the actual diameter of the dendritic tree. Based on the same logic used for the on-cell, a reasonable range for the diameter is between 25 and $45 \mu \mathrm{m}$. We suggest that the dendritic trec was 30-35 $\mu \mathrm{m}$ wide, and we have represented this by a $35 \mu \mathrm{m}$ circle inscribed about the primary dendrite on Figure 6. By comparing the rotated reconstructions (Figs. 4 and 7, top; Fig. 6, combined), one can see that the dendritic tree branching pattern for the on- $\beta$ cell looks almost identical to the branching pattern for the off- $\beta$ cell, another indication that they belong to the same kind of ganglion cell class.

\section{"Bushiness" of the beta cells}

The dendritic arbors of $\beta$ cells are often referred to as "bushy" in contrast to the "radiate" pattern of $\alpha$ cells. Information contained in the branch schematic permitted a quantitative expression of this difference. The arbor appears bushy because the dendrites bifurcate frequently over rather short distances. For example, two of the on $-\beta$ cell's dendrites branched $4 \times$ within $17 \mu \mathrm{m}$, and three of the off $\beta$ dendrites branched $4 \times$ within 13 $\mu \mathrm{m}$. The average length for those branches ending in bifurcations (therefore complete) was $3.82 \mu \mathrm{m}$ for the on- $\beta$ cell $(n=22)$ and $3.74 \mu \mathrm{m}$ for the off- $\beta$ cell $(n=18)$. Alpha ganglion cells appear radiate rather than bushy because, although they bifurcate as many times as $\beta$ cells do, they do so over longer intervals. Thus, an $\alpha$ cell located near the area centralis (Fig. 2A, Boycott and Wässle, 1974) had four dendrites that each branched only $4 \times$ within $34 \mu \mathrm{m}$.

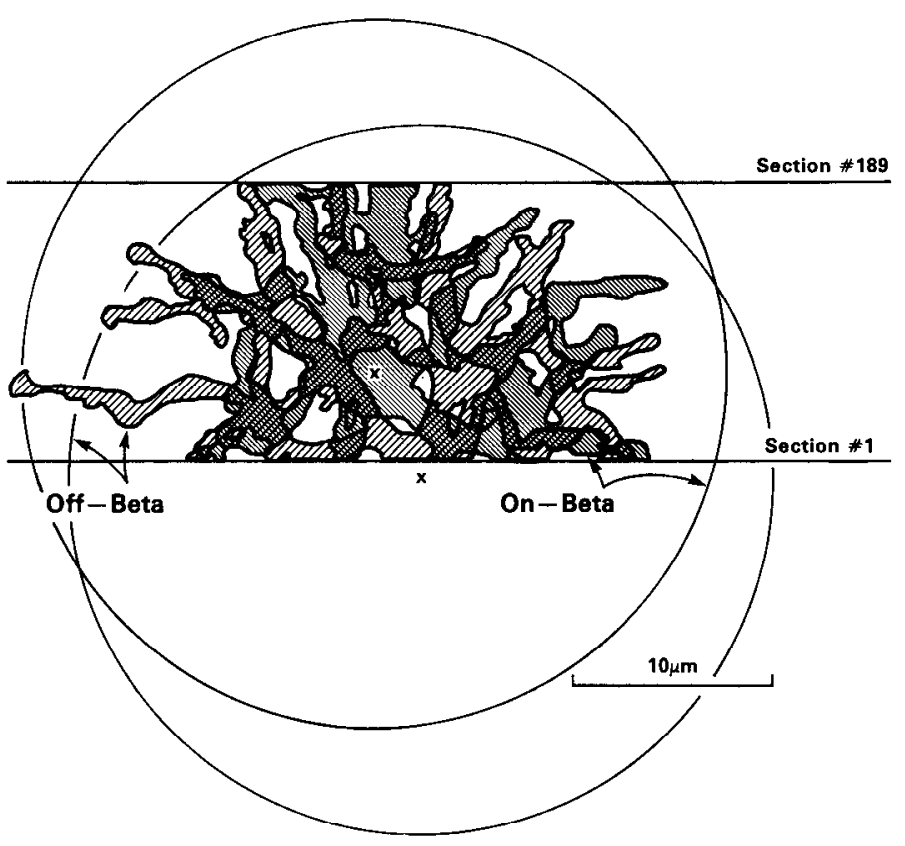

Figure 6. Diagram showing positions of the two $\beta$ cell dendritic trees, rotated $90^{\circ}$ about the $x$-axis, as if seen in a flat-mount. The two arbors are obviously co-spatial in the tangential plane. Circles indicate estimated total dendritic diameter of each cell (approximately $35 \mu \mathrm{m}$ ) using, in each case, the center of the stout primary dendrite $(x)$ as the center of the dendritic tree. Note the similarity of the size and bushy branching pattern of the two cells.

\section{Distribution of cone bipolar cell synaptic contacts to the on-beta cell}

We identified all of the synaptic interconnections among three cone bipolar cells branching in sublamina $b$ and a single postsynaptic on- $\beta$ cell, for a total of 103 synaptic contacts. Fortyseven and 22 of these contacts, respectively, derived from two adjacent $\mathrm{CBb}_{1}$ cone bipolars (cells 6 and 3; McGuire et al., 1984). Thirty-four contacts were derived from a different type of cone bipolar cell, $\mathrm{CBb}_{2}$ (cell 4; McGuire et al., 1984). The dendritic locations of all of the contacts of cells $6\left(\mathrm{CBb}_{1}\right)$ and cell $4\left(\mathrm{CBb}_{1}\right)$ were plotted on the $\beta$ cell reconstruction (Fig. 4) and also on the branch diagram (Fig. 5). Although not shown here, most of the dendrites that appear devoid of synaptic inputs do receive them, both from other cone bipolar cells and from amacrine cells. The specific arrangement of these synapses is currently under study (P. Sterling et al., unpublished observations). The contacts from both cone bipolar cells were distributed widely over the dendritic tree. Thus, cell $6\left(\mathrm{CBb}_{1}\right)$ contacted 17 branches on the $\beta$ cell ranging from the first through sixth order, while cell $4\left(\mathrm{CBb}_{2}\right)$ contacted 11 branches of the second through sixth order. Both cells tended to form clusters of three to five contacts on short stretches of on- $\beta$ dendrite.

Despite their wide distributions, contacts from the two bipolar cells showed little tendency to intermingle and, on average, occupied different regions of the dendritic arbor. This was true despite the fact that the two axons were overlapping in the tangential plane (see Fig. 9). Plotting of the contacts on the reconstruction (Fig. 4) showed that cell $6\left(\mathrm{CBb}_{1}\right)$ formed synapses mainly within stratum 5 and lower stratum 4 , while cell $4\left(\mathrm{CBb}_{2}\right)$ made its synapses mainly within upper stratum 4 . The basal tufts, which sprout proximally from the $\beta$ cell, collected more than half of the contacts $(28 / 47)$ from cell $6\left(\mathrm{CBb}_{1}\right)$ (see Fig. 10, bottom), but none from cell $4\left(\mathrm{CBb}_{2}\right)$. Similarly, the first through third order branches collected almost three-fourths 

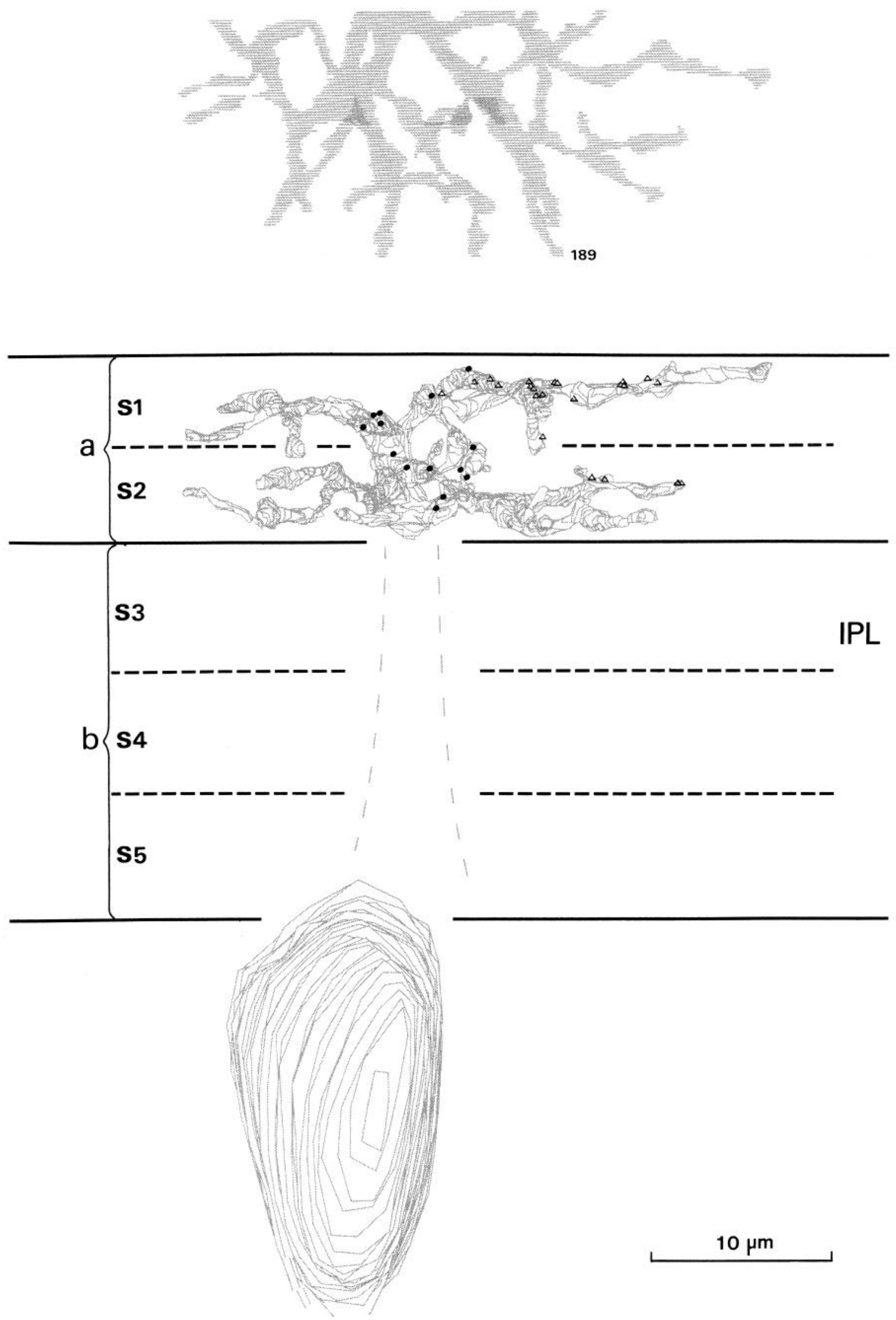

Figure 7. Below, Computer reconstruction of off- $\beta$ cell, as seen from rear of the series. The primary dendrite connecting soma with dendritic aborization was cut away; its approximate position is indicated by dashed lines. Although the synaptic contacts from the $\mathrm{CBa} \mathrm{a}_{2}$ cell $(\bullet)$ appear to be closer than those from the $\mathrm{CBa}_{1}$ cell $(\Delta)$ to the primary dendrite in the center of the picture, the relative placement of each set is almost equivalent, as can be seen in the branch diagram, Figure 8. Above, Projection of dendritic arbor of off- $\beta$ cell rotated $90^{\circ}$ about the $x$-axis; first and last sections indicated. 
Figure 8. Branch diagram of off- $\beta$ cell's dendritic arbor. The primary dendrite emitted four secondary branches, which each bifurcated into higher-order dendrites. Branches have been constructed from length measurements so that branch length can be measured from the diagram. Synaptic contacts from $\mathrm{CBa}_{1}(\triangle)$ and $\mathrm{CBa}_{2}$ $(\odot)$ are indicated in their approximate positions on the dendritic tree.

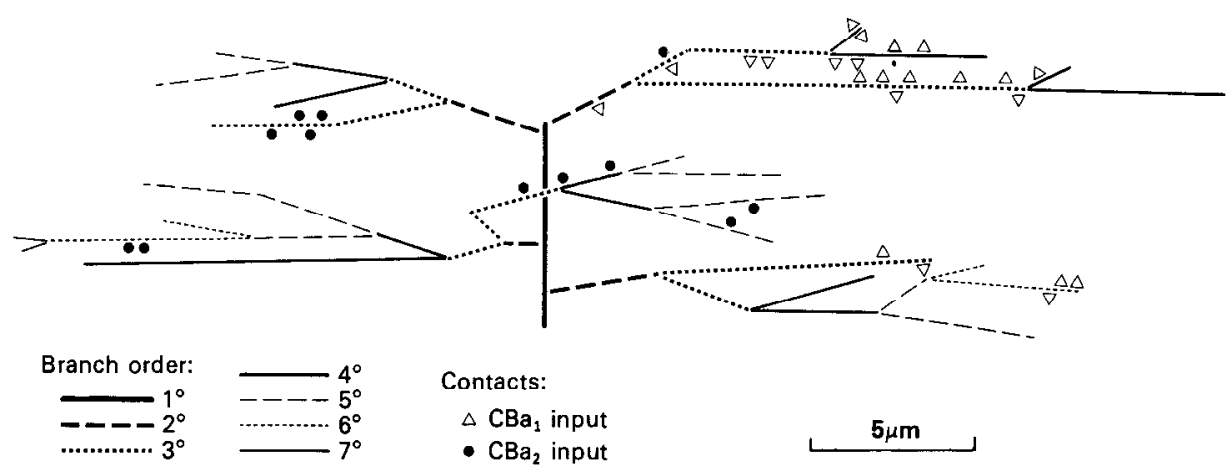

(72\%) of the contacts from cell 6 but less than half of those from cell 4 (Fig. 10, top).

It should be stressed that the on- $\beta$ cell described here received many bipolar cell inputs in the lower half of sublamina $b$, near the ganglion cell bodies. As just described, these were made by $\mathrm{CBb}_{1}$ onto the basal tufts of the on $\beta$ cell. In Figure 2, for example, one can see a dendritic profile of the on- $\beta$ cell (lower right, circled in white) almost touching a ganglion cell body, as well as a small profile nearby of $\mathrm{CBb}_{1}$. In Figure 4, many $\mathrm{CBb}_{1}$ synaptic contacts can be seen in S5. This feature of $\beta$ cells receiving inputs from cone bipolar cells so near the ganglion cell bodies was not apparent in earlier, less complete reconstructions (Stevens et al., 1980b; see also discussion, Wässle et al., 1981b).

\section{Divergence and convergence of cone bipolar cells onto the beta cell}

It is possible for a single cone bipolar cell to diverge and contact several $\beta$ cells because the dendritic trees of $\beta$ ganglion cells overlap in the inner plexiform layer (see Wässle et al., 1981a). Based on the coverage factor for $\beta$ ganglion cells, each cone bipolar cell axon here should largely overlap with at least two or three $\beta$ cell dendritic trees (Wässle et al., 1981a). Any particular cone bipolar might equally divide its $\beta$ cell contacts among all of the $\beta$ cell dendritic trees with which it overlaps. Although only based on a small sample, results described here suggest, instead, that the majority of a cone bipolar cell's contacts are directed to a single on- $\beta$ cell. Out of a total of 58 ribbon outputs from cell 6 onto dark ganglion ccll dendritcs (presumed $\beta$ cells), $47(81 \%)$ were made with a single on- $\beta$ cell. The remaining 11 postsynaptic dendrites could not be followed to their parent somas within the series, but possibly some or all of them also belong to the reconstructed $\beta$ cell. Of 39 contacts directed by cell $4\left(\mathrm{CBb}_{2}\right)$ to presumed $\beta$ cell dendrites, $34(87 \%)$ were to the reconstructed on $\beta$ cell, suggesting that this bipolar cell also diverged very little, if at all. One $\mathrm{CBb}_{1}$ cell reconstructed from a nearby region of the series provided many (33) contacts to one on- $\beta$ cell (Fig. 3, cell D) and a few (five) to the basal tuft of a different presumed on- $\beta$ ganglion cell (Fig 3, cell $C$ ) so the divergence of $\mathrm{CBb}_{1}$ cells in general may be somewhat greater than strictly one-to-one.

We know from the present results and from Kolb (1979) that several cone bipolar cells converge onto a single $\beta$ ganglion cell in the central area. In fact, considering just the $\mathrm{CBb_{1 }}$ cells, it is possible for the axonal trees of at least six $\mathrm{CBb}_{1}$ cells to largely overlap the dendritic tree of the on- $\beta$ cell described here, based on their diameters and relative spacing of about $12 \mu \mathrm{m}$ apart (M. A. Freed and P. Sterling, unpublished observations). The on- $\beta$ cell described here, which was probably between 30 and $50 \%$ complete, received convergent input from at least two $\mathrm{CBb}_{1}$ cells. A different pair of $\mathrm{CBb}_{1}$ cells was also found to converge (28 synapses from one, 25 from another) onto a nearby on- $\beta$ cell, which was also incomplete (Fig. 3, cell D). Unfortunately, it is impossible to tell from the partial reconstructions reported here exactly how many $C B b_{1}$ cells do converge on a single on- $\beta$ cell near the area centralis, but it is probably in the range of three to six.

\section{Distribution of cone bipolar cell synaptic contacts to the off-beta cell}

We identified a total of 35 cone bipolar cell contacts on the off- $\beta$ cell dendritic tree (Fig. 8). Twenty-three of these were

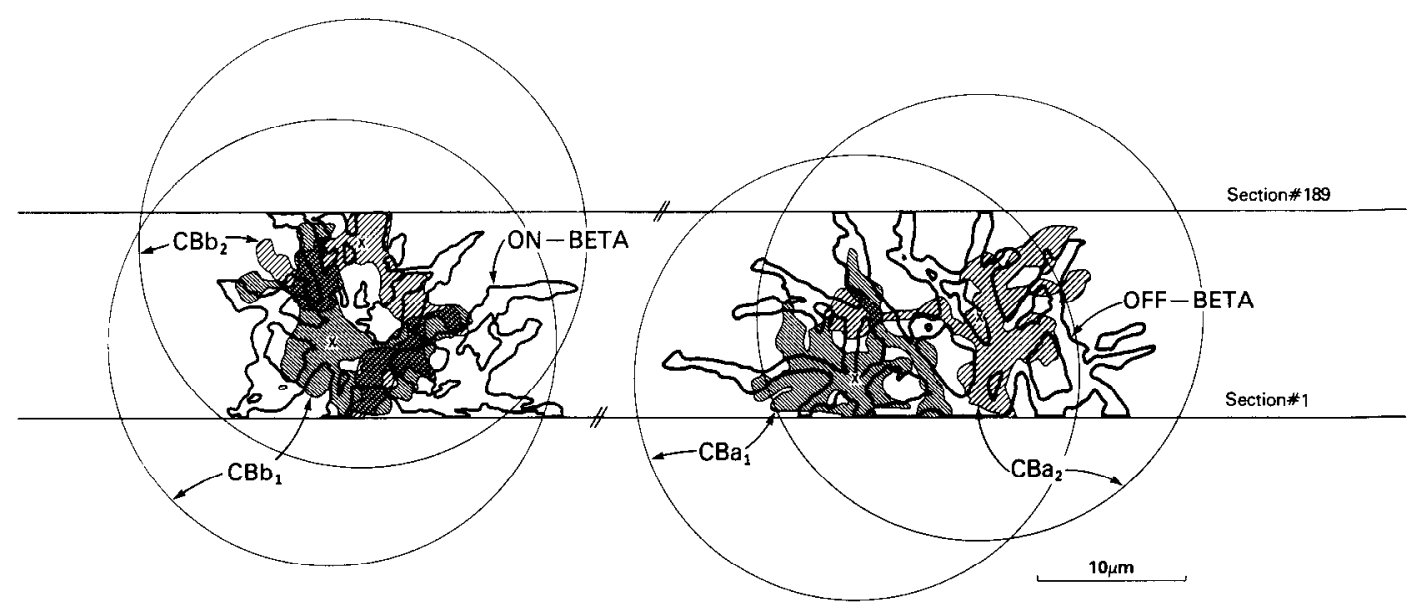

Figure 9. Diagram showing positions of the pairs of presynaptic bipolar cell axons and their postsynaptic $\beta$ cells, rotated $90^{\circ}$ about the $x$-axis, as if seen in a flat-mount. The positions of the bipolar primary axonal processes are indicated $(x)$. The approximate size of a cone bipolar cell's dendritic arborization (from Kolb et al., 1981) is indicated by $30 \mu \mathrm{m}$ wide circles. 
derived from a single $\mathrm{CBa}_{1}$ bipolar (cell 1; McGuire et al., 1984). These contacts were distributed widely over the dendritic tree, on branches ranging from the second through sixth order, and again some of the contacts were clustered. The other 12 contacts were made by a single $\mathrm{CBa}_{2}$ bipolar (cell 5; McGuire et al., 1984 ), on seven branches from the third through the sixth order (Fig. 8). This pattern was confirmed in a second off- $\beta$ in the same series (Fig. 3, cell E), which received 16 contacts from a single $\mathrm{CBa}_{1}$ and 23 from a single $\mathrm{CBa}_{2}$ (cells 14 and 15 ; McGuire et al., 1984). There was no statistically significant difference in the relative location of the inputs from the two types of cone bipolar cells (see Fig. 11), though the sample is small compared with what was gathered for the on- $\beta$ cell, where a difference was more apparent.

Although it appears that the reconstructed cone bipolar synaptic input was much sparser for the off- $\beta$ cell than for the on- $\beta$ cell, this was probably just due to a sampling difference. The proportion of cone bipolar ribbon outputs directed to dark ganglion cell dendrites (presumed $\beta$ cells) was about the same for the four cone bipolar cells described here (about 33\% for the sublamina b bipolars; about $29 \%$ for the sublamina a bipolar cells; see McGuire et al., 1984). However, not only were more total outputs recovered for the sublamina $b$ pair (145 contacts) compared with the sublamina a pair (111 contacts), but a higher proportion of the postsynaptic dendrites in sublamina $b$ were followed to a parent cell body. The result was that 81 contacts were reconstructed for the on- $\beta$ cell, whereas only 35 were found for the off- $\beta$ cell. We have no reason to believe that this was due to any reason other than the fact that the on-cell and its presynaptic bipolar cells were better centered within the series, and thus more completely reconstructed.

\section{Discussion}

It is commonly belicved from work on several species that retinal cone bipolar cells excite their postsynaptic ganglion cells (see, e.g., Miller and Dacheux, 1976; Famiglietti et al., 1977; Miller and Dacheux, 1976; Naka, 1977; Nelson et al., 1978). Compared, however, with our knowledge of fish and mudpuppy retinas, our understanding of the physiological propertics of cone bipolar cells in the cat is still less complete (Nelson and Kolb, 1983). The possibility that all cone bipolar cells are excitatory was an attractive hypothesis when there were only three or so different types of cone bipolar cell known in the cat (see, e.g., Boycott and Kolb, 1973; Nelson et al., 1978). In this simple scheme, a single type of invaginating, depolarizing cone bipolar cell provided the excitatory input to on-center ganglion cells, and one or two types of flat, hyperpolarizing cone bipolar cells provided the excitatory input to off-center ganglion cells. In a previous paper (McGuire et al., 1984), we showed that there are at least six types of cone bipolar cells in the cat, in agreement with Golgi studies (Famiglietti, 1981; Kolb et al., 1981) and intracellular HRP injections (Nelson and Kolb, 1983). Here, we show the detailed microcircuitry between two different types of cone bipolar cells and an on-center $\beta$ ganglion cell, and two different types of cone bipolar cells and an off-center $\beta$ ganglion cell. The results of the present study cannot rule out a purely excitatory scheme of bipolar-to-ganglion cell connectivity, in which both bipolar cells of a presynaptic pair excite their postsynaptic $\beta$ cell. If this were the case, though, one wonders why, for example, an on- $\beta$ ganglion cell would require inputs from two different types of depolarizing bipolar cells. The present results are also consistent with an alternative to this purely excitatory bipolar-to-ganglion cell connectivity scheme. This different possible mechanism for generating $\beta$ ganglion cell receptive fields makes use of the fact that there are two parallel cone bipolar cell pathways to each kind of $\beta$ ganglion cell; it is described below.

The dendritic trees of the cone bipolar cells presynaptic to a
Distribution of inputs to On-Beta cell
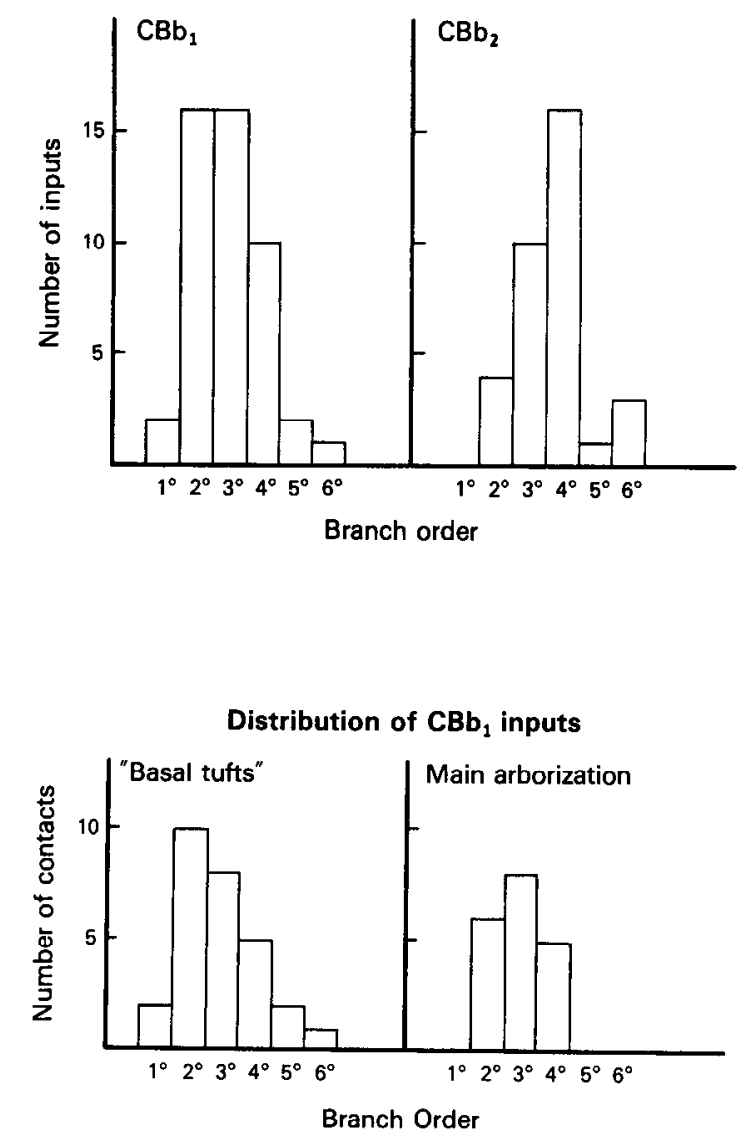

Figure 10. Top, Histogram of branch order positions of synaptic contacts reconstructed for on $-\beta$ cell. Most of the 47 inputs from $C B b_{1}$ were on secondary and tertiary branches. Most of the 34 inputs from $\mathrm{CBb}_{2}$ were on tertiary and quaternary branches. Bottom, Histogram of branch order positions of $\mathrm{CBb}$, contacts to basal tuft dendrites and contacts to the main arborization. The majority (28) of the $47 \mathrm{CBb}_{1}$ contacts were on the basal tufts.

$\beta$ ganglion cell almost ccrtainly ovcrlap extensively in the outer plexiform layer. For $\mathrm{CBa}_{1}$ and $\mathrm{CBb}_{2}$ (see Fig. 1), the dendrites were partially recovered in the outer plexiform layer, lying just above the $\beta$ cells' dendritic trees. For the two other bipolar cells $\left(\mathrm{CBa}_{2}\right.$ and $\left.\mathrm{CBb}_{1}\right)$, the dendrites were not reconstructed, but from the correspondence of each with more fully rcconstructcd examples (cells 15 and 11; McGuire et al., 1984), we believe that the dendrites probably lie directly above the axonal arborization and thus, again, directly above the $\beta$ cells' dendritic trees (see also Kolb et al., 1981). Therefore, the pairs of bipolar cell types that innervate on $-\beta$ cells $\left(\mathrm{CBb}_{1}\right.$ and $\left.\mathrm{CBb_{2 }}\right)$ and off- $\beta$ cells $\left(\mathrm{CBa}_{1}\right.$ and $\mathrm{CBa}_{2}$ ) appear to collect from a patch of photoreceptors cospatial with the $\beta$ cell dendritic trees (see Fig. 9). This suggests that the pairs of cone bipolar cells described here that innervate each $\beta$ ganglion cell must contribute to the receptive field centers.

The two cone bipolar cell types that we find to be co-spatial with the on- $\beta$ cell dendritic tree and to provide it with multiple contacts have been observed by intracellular recording to give opposite responses to light. Nelson and Kolb (1983) found $\mathrm{CBb}_{1}$ (which they call "cb5"; see McGuire et al., 1984) to depolarize to a central spot of light and hyperpolarize to an annulus. This on-center $C B b_{1}$ is believed to be excitatory mainly because it provides the major bipolar cell input to the on-center $\alpha(\mathrm{Y})$ ganglion cell (Freed and Sterling, 1983), as well as to the oncenter $\beta(\mathrm{X})$ ganglion cell. Nelson and Kolb (1983) reported that 


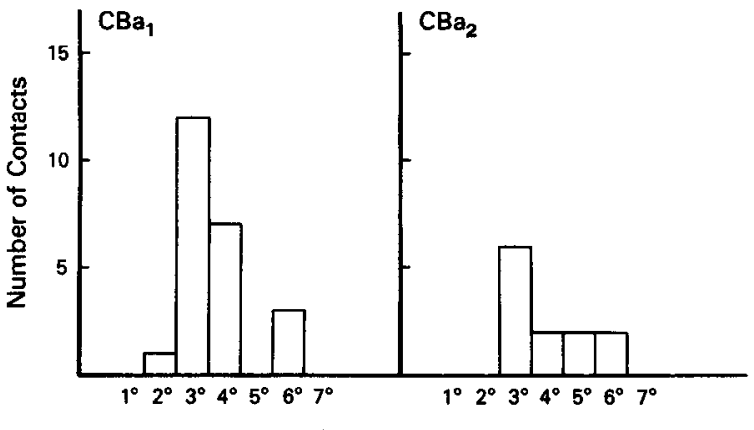

Branch order

Figure 11. Histogram of branch order positions of synaptic contacts from $\mathrm{CBa}_{1}$ and $\mathrm{CBa}_{2}$ with off- $\beta$ cell. Both cells made most of their synaptic contacts with secondary and tertiary dendrites.

$\mathrm{CBb}_{2}$ (their "cb6") hyperpolarizes to a spot and is without evidence of a surround. If $\mathrm{CBb}_{2}$ were also excitatory, it is hard to imagine what function it would serve, since it would then tend to excite the on- $\beta$ cell at the very moment that the ganglion cell is turning of and would tend to withdraw excitation when the ganglion cell is turning on. We have postulated, therefore, that $\mathrm{CBb}_{2}$ is inhibitory, releasing transmitter in the dark at multiple sites on the $\beta$ cell, especially on the distal branches. At light on, this inhibition would cease abruptly, cotemporally with the delivery of excitation from $\mathrm{CBb}_{1}$.

Thus, the $\beta$ cell's on response to illumination of its receptive field center may result from two cooperative processes: increasing excitation (via on-center $\mathrm{CBb}_{1}$ at sign-conserving synapses) and decreasing inhibition (via off-center $\mathrm{CBb}_{2}$ at sign-inverting synapses; see Fig. 12). The $\beta$ cell's sharp decline in response to darkening of its receptive field center would result from a reversal of these two processes. Illumination of $\mathrm{CBb}_{1}$ 's antagonistic surround would also cut off excitation to the $\beta$ cell. A surround was not found for $\mathrm{CBb}_{2}$; however, only a few examples have becn studicd physiologically, so the possibility that onc exists is not completely excluded. At present, one may suggest that the off surround is generated at least in part by the withdrawal of $\mathrm{CBb}_{1}$ excitation, with the possibility of an additional contribution of active postsynaptic inhibition from $\mathrm{CBb}_{2}$.

This model does not rule out the possibility that amacrine cells can contribute to the inhibition and disinhibition of $\beta$ ganglion cells within the inner plexiform layer. It is known that amacrine cell synapses constitute about $30 \%$ of the inputs to these ganglion cells, and so they are apt to play an important role in influencing the $\beta$ cell receptive fields. If the receptive fields of most cone bipolar cells in fact lack surrounds, then amacrine cells would be the likeliest source for generating the $\beta$ cell surround receptive field.

The center of the $\beta$ cell's receptive field is larger than its dendritic field at a given eccentricity, and this has been something of a puzzle. In the area centralis, for example, the diameter of the receptive field center is about $66 \mu \mathrm{m}$ (Peichl and Wässle, 1979), while the smallest dendritic field diameter is $20-32 \mu \mathrm{m}$ (Boycott and Wässle, 1974), corrected for shrinkage (see Kolb et al., 1981; Peichl and Wässle, 1979). Our observation that several bipolars of each type contribute multiple contacts to a $\beta$ cell suggests that the receptive field center should correspond not to the $\beta$ cell's dendritic field, but rather to the envelope of the receptive fields of the cone bipolar cells that provide its contacts (as discussed by Peichl and Wässle, 1979). An initial indication of this size is shown in Figure 9, in which the outlines of just two cone bipolar dendritic trees (approximate sizes from Kolb et al., 1981) are plotted on the tangential view of the on- $\beta$ cell's reconstructed dendrites. If these dendritic estimates are

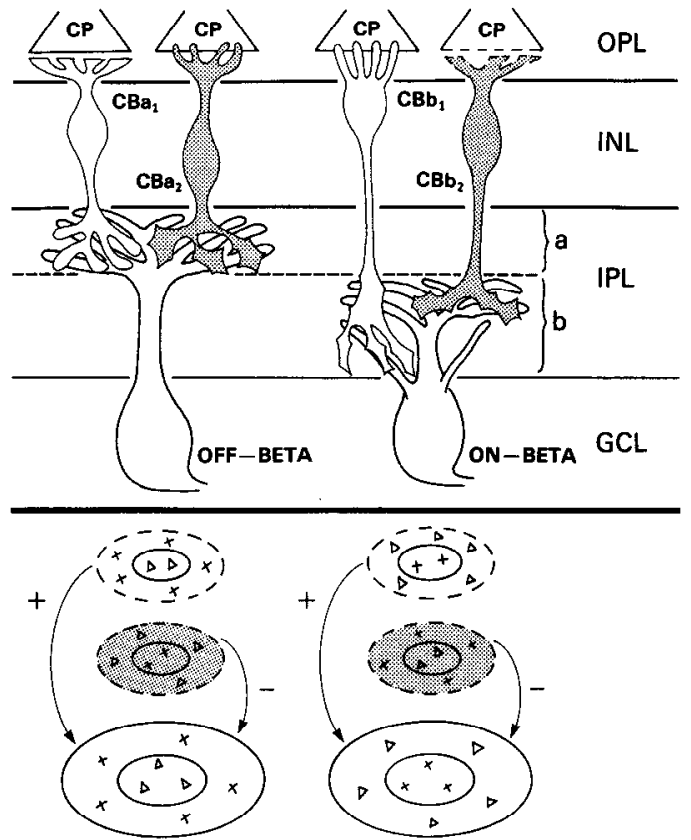

Figure 12. Schematic representing the "push-pull" hypothesis. Above, Bipolar cells and postsynaptic $\beta$ cells. Left, $\mathrm{CBa}_{1}$ receives flat contacts from cones; $\mathrm{CBa}_{2}$ (shaded) receives ribbon-related cone contacts (McGuire et al., 1984). Both contact the off- $\beta$ cell. Right, $\mathrm{CBb}_{1}$ receives semi-invaginating cone contacts (Kolb et al., 1981); the nature of the cone inputs to $\mathrm{CBb}_{2}$ is less clear (dashed lines). Both contact the on- $\beta$ cell. Below, Hand-plots of hypothesized receptive field organization of cells above. In this scheme, on the left, $\mathrm{CBa}_{1}$ (off-center) cone bipolar excites the off- $\beta$, and a co-spatial $\mathrm{CBa}_{2}$ (presumed on-center, shaded) cone bipolar inhibits it. (Since a receptive field surround has only been seen for the cone bipolar $\mathrm{CBb}_{1}$, we have indicated the bipolar cell surrounds only by dashed lines.) Right, $\mathrm{CBb}_{1}$ (on-center) cone bipolar excites the on- $\beta$, and a co-spatial $\mathrm{CBb}_{2}$ (off-center, shaded) cone bipolar inhibits the on $-\beta$.

roughly correct, one would expect that the receptive field envelope of the two to six $C B b_{1}$ s presynaptic to an on- $\beta$ would be substantially larger than the $\beta$ cell dendritic tree.

A similar mechanism may be responsible for the receptive field of the off- $\beta$ cell (Fig. 12). The dendrites of the $C B a_{1}$ and $\mathrm{CBa}_{2}$ bipolars overlap in the outer plexiform layer and are cospatial with the off- $\beta$ cell's dendritic tree (Fig. 9) to which they both provide multiple contacts. $\mathrm{CBa}_{1}$ receives "flat" contacts from cones and is hyperpolarizing and thought to be excitatory. $\mathrm{CBa}_{2}$ receives "invaginating" contacts from cones (McGuire et al., 1984) and may be depolarizing and inhibitory (McGuire et al., 1984; Nelson and Kolb, 1983). Excitation of the off- $\beta$ cell on darkening its center would be due to increased excitation (via off-center $\mathrm{CBa}_{1}$ at sign-conserving synapses) and simultaneous decreased inhibition (via on-center $\mathrm{CBa}_{2}$ at sign-inverting synapses); suppression of the off- $\beta$ cell's firing on illuminating its center would be due to decreased facilitation (from off-center $\mathrm{CBa}_{1}$ ) and increased inhibition (from on-center $\mathrm{CBa}_{2}$; see Fig. 12 ). This mechanism would account as well for the off- $\beta$ cell's antagonistic surround if the cone bipolar cells themselves have surrounds, but these have not yet been reported for bipolars in sublamina a. If these cone bipolar cell surrounds are nonexistent, then the off- $\beta$ cell surround must be generated completely within the inner plexiform layer, presumably by amacrine cells.

The model described here implies that $\beta$ cells receive sustained inhibitory inputs. Sustained IPSPs have been recorded in mudpuppy ganglion cells (Belgum et al., 1982), and in the cat there is pharmacological evidence for sustained inhibition 
to ganglion cells. Thus, strychnine increases the maintained activity of both on- and off-center ganglion cells (Bolz et al., 1985b; Kirby, 1979; Saito, 1981), suggesting a tonic release of glycine onto ganglion cells. This may be correlated with the fact that certain bipolar cells are labeled by uptake of tritiated glycine (Nakamura et al., 1978; Pourcho, 1980), but further identifcation of the types of glycine-accumulating bipolar cells remains to be done. In addition, it is not yet clear whether the release of glycine on $\beta$ ganglion cells is strictly from bipolar cells, strictly from amacrine cells, or perhaps from both. The GABA-blocker, bicuculline, also increases the maintained activity of on-center cells (Bolz et al., 1985a; Saito, 1981), but there has been no suggestion that any bipolar cell in the cat retina is GABAergic (Freed et al., 1983; Pourcho, 1980).

Slaughter and Miller (1981) showed that application of a drug, 2-amino 4-phosphonobutyric acid (APB), which is thought to mimic the action of the photoreceptor transmitter, blocks the response of on-center bipolar cells. In addition, APB has been shown to block the response of on-center ganglion cells (Bolz et al., 1984; Horton and Sherk, 1984). This is presumably due to the removal of the excitatory on-center cone bipolar input. There is evidence that APB also affects off-ganglion cells. Bolz and colleagues (1984) found that APB administration increased the spontaneous activity of off-center ganglion cells without abolishing the light response. This result would be consistent with the blocking of a tonic inhibition via on-center cone bipolars and thus supports the idea of a cooperative mechanism.

The circuits proposed here for the $\beta$ cells remind one of a push-pull amplifier whose output is the sum of two alternately active, opposing currents. Among the advantages of this differential arrangement in the electronic circuit are an increased dynamic range and shortened time constant of response. The dynamic range of ganglion cells observed by Kuffler (1953) was high, 0-700 spikes/sec. Further, the "briskness" of response, which is characteristic of the $\beta$ cell (Cleland and Levick, 1974) may be a qualitative expression of a short time constant of response. Another characteristic of the $\beta$ cell receptive field is that the center excitation and center inhibition are relatively independent of one another (Stein et al., 1983), which would be consistent with a push-pull kind of mechanism. Finally, a hallmark of the $\beta$ cell receptive field is the mutual antagonism between its center and surround (Kuffler, 1953). If the surround were also generated by a push-pull mechanism (Fig. 12), the center-surround antagonism might be stronger for having the center and surround push-pulled in opposite directions.

Several specific features of the synaptic pattern may also be of significance for the $\beta$ cell's response. The multiple contacts from each bipolar cell are not restricted to a single stretch of dendrite but are widely distributed to dendrites of almost all orders. Rall (1967) pointed out on theoretical grounds that such a distribution would be required for the postsynaptic contacts to sum linearly. This arrangement might, therefore, be related to the $\beta$ cell's property of linear spatial summation (EnrothCugell and Robson, 1966).

Another unusual feature is that the presumed inhibitory contacts on the $\beta$ cells $\left(\mathrm{CBb}_{2}\right.$ to the on $-\beta$ cell and $\mathrm{CBa}_{2}$ to the off- $\beta$ ) are interspersed with the presumed excitatory contacts and for the on $\beta$ cell, tend to be distal to the excitatory contacts. In the CNS, inhibitory contacts are commonly found proximally on the soma and axon initial segment of nerve cells, where they are said to have "veto" power. The role of synaptic inhibition on the $\beta$ cell, however, may not be to veto excitation, but rather to act with it cooperatively. Kuffler (1953) remarked in his original description on the "flexibility and fluidity of the discharge patterns arising in each receptive field," and this may be related to the distribution of inhibitory contacts. Kuffler also observed, as have others since, that the surround of the $\beta$ cell can never entirely suppress the center response. If synaptic in- hibition from $\mathrm{CBb}_{2}$ is important in establishing the surround of the on $-\beta$ cell, as we suggest (Fig. 12), the inability of the surround to dominate the center may be related to the inhibitory $\mathrm{CBb}_{2}$ contacts being, on the average, distal to the excitatory ones. It will be important to extend this model by learning more about the distribution of contacts on the $\beta$ cells from the other types of bipolar cell as well as the various types of amacrine cells. Perhaps the most obvious outstanding question, though, is to find out more about the physiological properties of the various neurons presynaptic to the $\beta$ ganglion cells.

\section{References}

Belgum H. H., D. R. Dvorak, and J. S. McReynolds (1982) Sustained synaptic input to ganglion cells of the mudpuppy retina. J. Physiol. (Lond.) 326: 91-108.

Bolz, J., H. Wässle, and P. Thier (1984) Pharmacological modulation of on and off ganglion cells in the cat retina. Neuroscience 12:875885.

Bolz, J., T. Frumkes, T. Voight, and H. Wässle (1985a) Action and localization of $\gamma$-aminobutyric acid in the cat retina. J. Physiol. (Lond.) 362: 369-393.

Bolz, J., P. Thier, T. Voight, and H. Wässle (1985b) Action and localization of glycine and taurine in the cat retina. J. Physiol. (Lond.) 362: 395-413.

Boycott, B. B., and H. Kolb (1973) The connections between bipolar cells and photoreceptors in the retina of the domestic cat. J. Comp. Neurol. 148: 91-114.

Boycott, B. B., and H. Wässle (1974) The morphological types of ganglion cells of the domestic cat's retina. J. Physiol., (Lond.) 240: $397-419$.

Cleland, B. G., and W. R. Levick (1974) Properties of rarely encountered types of ganglion cells in the cat's retina. J. Physiol. (Lond.) 240: 457-492.

Cleland, B. G., M. W. Dubin, and W. R. Levick (1971) Sustained and transient neurones in the cat's retina and lateral geniculate nucleus. J. Physiol. (Lond.) 217: 473-496.

Enroth-Cugell, C., and J. G. Robson (1966) The contrast sensitivity of retinal ganglion cells of the cat. J. Physiol. (Lond.) 187: 517-552.

Famiglietti, E. V., Jr. (1981) Functional architecture of cone bipolar cells in mammalian retina. Vision Res. 21: 1559-1564.

Famiglietti, E. V., Jr., A. Kaneko, and M. Tachibana (1977) Neuronal architecture of on and off pathways to ganglion cells in carp retina. Science 198: 1267-1269.

Freed, M. A., and P. Sterling (1983) Spatial distribution of input from depolarizing cone bipolars to dendritic tree of on-center alpha ganglion cell. Soc. Neurosci. Abstr. 9: 806.

Freed, M. A., Y. Nakamura, and P. Sterling (1983) Four types of amacrine in the cat retina that accumulate GABA. J. Comp. Neurol. 219: 295-304.

Fukuda, Y. (1971) Receptive field organization of cat optic nerve fibers with special reference to conduction velocity. Vision Res. 11: 209226.

Fukuda, Y., C.-F. Hsiao, M. Watanabe, and H. Ito (1984) Morphological correlates of physiologically identified $Y_{-}, X_{-}$and W-cells in the cat retina. J. Neurophysiol. 52: 999-1013.

Horton, J., and H. Sherk (1984) Receptive field properties in the cat's lateral geniculate nucleus in the absence of on-center retinal input. $J$. Neurosci. 4: $374-380$

Kirby, A. W. (1979) The effect of strychnine, bicuculline, and picrotoxin on $X$ and $Y$ cells in the cat retina. J. Gen. Physiol. 74: 71-84.

Kolb, H. (1979) The inner plexiform layer in the retina of the cat: electron microscope observations, J. Neurocytol. 8: 295-329.

Kolb, H., R. Nelson, and A. Mariani (1981) Amacrine cells, bipolar cells and ganglion cells of the cat retina: A Golgi study. Vision Res. 21: $1081-1114$.

Kuffler, S. W. (1953) Discharge patterns and functional organization of mammalian retina. J. Neurophysiol. 16: 47-68.

McGuire, B. A., J. K. Stevens, and P. Sterling (1980) Beta ganglion cells receive convergent input from two types of cone bipolar. Soc. Neurosci. Abstr. 6: 347.

McGuire, B. A., J. K. Stevens, and P. Sterling (1982) "Push-pull" microcircuitry of the beta $(X)$ ganglion cell in light adaptation. Invest. Ophthalmol. Vis. Sci. (Suppl.) 22: 3. 
McGuire, B. A., J. K. Stevens, and P. Sterling (1984) Microcircuitry of bipolar cells in cat retina. J. Neurosci. 4: 2920-2938.

Miller, R. F., and R. F. Dacheux (1976) Synaptic organization and ionic basis of on and off channels in mudpuppy retina. III. A model of ganglion cell receptive field organization based on chloride-free experiments. J. Gen. Physiol. 67: 679-690.

Naka, K.-I. (1977) Functional organization of catfish retina. J. Neurophysiol. 40: 26-43.

Nakamura, Y., B. McGuire, and P. Sterling (1978) Selective uptake of $\gamma-\left[{ }^{3} \mathrm{H}\right]$-aminobutyric acid and $\left[{ }^{3} \mathrm{H}\right]$ glycine by neurons of the amacrine layer of cat retina. Neurosci. Soc. Abstr. 4: 2046.

Nelson, R., and H. Kolb (1983) Synaptic patterns and response properties of bipolar and ganglion cells in the cat retina. Vision Res. 23: 1183-1195.

Nelson, R., E. V. Famiglietti, Jr., and H. Kolb (1978) Intracellular staining reveals different levels of stratification for ON- and OFFcenter ganglion cells in cat retina. J. Neurophysiol. 2: 472-483.

Peichl, L., and H. Wässle (1979) Size, scatter, and coverage of ganglion cell receptive field centers in cat retina. J. Physiol. (Lond.) 291: 117141.

Pourcho, R. (1980) Uptake of $\left[{ }^{3} \mathrm{H}\right]$ glycine and $\left[{ }^{3} \mathrm{H}\right] \mathrm{GABA}$ by amacrine cells in the cat retina. Brain Res. 198: 333-346.

Rall, W. (1967) Distinguishing theoretical synaptic potentials computed for different soma-dendritic distributions of synaptic input. J. Neurophysiol. 30: 1138-1168.

Saito, H.-A. (1981) The effects of strychnine and bicuculline on the responses of $\mathrm{X}$ - and $\mathrm{Y}$-cells of the isolated eye-cup preparation of the cat. Brain Res. 212: 243-248.
Saito, H.-A. (1983) Morphology of physiologically identified X-, Y-, and W-type retinal ganglion cells of the cat. J. Comp. Neurol. 221. 279-288.

Slaughter, M. M., and R. F. Miller (1981) 2-Amino-4-phosphonobutyric acid: A new pharmacological tool for retina research. Science 211: $182-185$

Stanford, L., and S. M. Sherman (1984) Structure/function relationship of retinal ganglion cells in the cat. Brain Res. 297: 381-386.

Stein, A., W. Mullikin, and J. Stevens (1983) The spatiotemporal building blocks of X-, Y- and W-ganglion cell receptive fields of the cat's retina. Exp. Brain Res. 49: 341-352.

Sterling, P. (1983) Microcircuitry of the cat retina. Annu. Rev. Neurosci. 6: 149-185.

Stevens, J. K., T. L. Davis, N. Friedman, and P. Sterling (1980a) A systematic approach to reconstructing microcircuitry by electron microscopy of serial sections. Brain Res. Rev. 2: 265-293.

Stevens, J. K., B. A. McGuire, and P. Sterling (1980b) Toward a functional architecture of the retina: serial reconstruction of adjacent ganglion cells. Science 207: 317-319.

Wässle H., B. B. Boycott, and R.-B. Illing (1981a) Morphology and mosaic of ON- and OFF-beta cells in the cat retina and some functional considerations. Proc. R. Soc. Lond. [Biol.] 212: 177-195.

Wässle H., L. Peichl, and B. B. Boycott (1981b) Morphology and mosaic of on- and off-alpha cells in the cat retina. Proc. R. Soc. Lond. [Biol.] 212: 157-175. 